
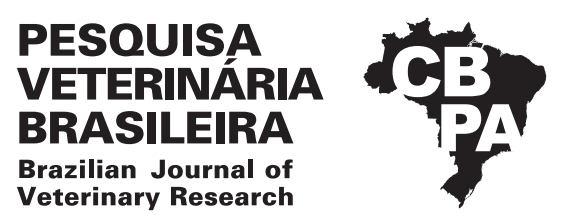

Pesq. Vet. Bras. 38(10):1896-1901, outubro 2018 DOI: $10.1590 / 1678-5150-P V B-5629$

Original Article

ISSN 0100-736X (Print)

ISSN 1678-5150 (Online)

\title{
Evidence of bovine viral diarrhea virus transmission by back pond water in experimentally infected piglets ${ }^{1}$
}

\author{
Karla A. Nascimento², Marina L. Mechler², Igor R.H. Gatto², \\ Henrique M.S. Almeida ${ }^{2}$, Andressa S. Pollo ${ }^{3}$, Fabiano J.F. Sant'Ana ${ }^{4}$, \\ Pedro M.O. Pedroso ${ }^{5}$ and Luís G. de Oliveira ${ }^{2 *}$
}

\begin{abstract}
Nascimento K.A., Mechler M.L., Gatto I.R.H., Almeida H.M.S., Souza-Pollo A., Sant'Ana F.J.F., Pedroso P.M.O. \& Oliveira L.G. 2018. Evidence of bovine viral diarrhea virus transmission by back pond water in experimentally infected piglets. Pesquisa Veterinária Brasileira 38(10):1896-1901. Laboratório de Pesquisa em Suínos, Departamento de Clínica e Cirurgia Veterinária, Faculdade de Ciências Agrárias e Veterinárias, Universidade Estadual Paulista "Júlio de Mesquita Filho", Via de acesso Prof. Paulo Donato Castellane, Jaboticabal, SP 14884-900, Brazil. E-mail: luis.guilherme@unesp.br

Swine can be infected by bovine viral diarrhea virus (BVDV). However, transmission routes among pigs are still unknown. The objective of the present study was to induce experimental infection of BVDV-1 in weaned piglets and to assess the potential transmission through pen back pond water, used to facilitate heat exchange of the pigs housed in barns. Two repetitions (BP1 and BP 2) were performed using 12 piglets proven to be free BVDV $(\mathrm{n}=6$ per repetition) allocated into three groups: control, sentinels and infected with two piglets each. The piglets were placed in stainless steel isolators. The infected group received an inoculum containing BVDV-1, Singer strain. The piglets remained in the cabinets for 25 days, during which samples of nasal swab were collected daily and blood sampled weekly. At the end, the piglets were euthanized, necropsied and organ fragments were collected for histopathology, immunohistochemistry and RT-PCR. In the first experiment (BP1) the infected animals shed the virus between days 6 and 21 post-infection. Regarding the sentinel group, shedding occurred in only one piglet, on the 20th day after infection, and seroconversion was observed on the 25th day post-infection. In BP2, infected piglets I3 and I4 shed the virus on days 4 and 21 post-infection, respectively. Only one sentinel piglet (S3) she the virus on day 13 post-infection. Therefore, it was concluded that pigs can become infected with BVDV-1 and shed potentially infectious viral particles consequently, being able to transmit the virus to other pigs through back pond water.
\end{abstract}

INDEX TERMS: Bovine viral diarrhea, weaned piglets, pestivirus, swine, RT-PCR, viroses.

\footnotetext{
${ }^{1}$ Received on January 24, 2018.

Accepted for publication on April 26, 2018.

Part of the MSc Dissertation of the senior author, Programa de Pós-Graduação em Medicina Veterinária.

${ }^{2}$ Laboratório de Pesquisa em Suínos, Departamento de Clínica e Cirurgia Veterinária, Faculdade de Ciências Agrárias e Veterinárias, Universidade Estadual Paulista (Unesp), Via de acesso Prof. Paulo Donato Castellane, Jaboticabal, SP 14884-900. *Corresponding author: luis.guilherme@unesp.br

${ }^{3}$ Laboratório de Medicina Veterinária Preventiva e Reprodução Animal, Faculdade de Ciências Agrárias e Veterinárias, Universidade Estadual Paulista (Unesp), Via de Acesso Prof. Paulo Donato Castellane, Jaboticabal, SP 14884-900.

${ }^{4}$ Laboratório de Diagnóstico Patológico Veterinário, Faculdade de Agronomia Veterinária (FAV), Universidade de Brasília (UNB), Brasília, DF 70297-400, Brazil.

${ }^{5}$ Laboratório de Patologia Veterinária, Universidade de Brasília (UNB), Campus Universitário Darcy Ribeiro, Via L4 Norte s/n, Brasília, DF 70910-970.
}

RESUMO.- [Evidência da transmissão do vírus da diarreia viral bovina através da lâmina d'água em leitões experimentalmente infectados.] Os suínos podem ser infectados pelo vírus da diarreia viral bovina (BVDV). No entanto, as vias de transmissão entre os suínos são ainda desconhecidas. $\mathrm{O}$ objetivo do presente estudo foi induzir a infecção experimental de BVDV-1 em leitões desmamados e avaliar a potencial transmissão pela lâmina d'água, que ajuda na troca de calor dos suínos alojados em baias. Duas repetições do experimento (BP1 e BP2) foram realizadas com 12 animais comprovadamente livres de BVDV $(n=6$ por repetição) alocados em três grupos: controle, sentinelas e infectados, com dois animais cada. Os animais foram mantidos em isoladores de aço inoxidável. 0 grupo infectado recebeu um inóculo contendo BVDV-1, estirpe Singer. Os animais 
permaneceram nos isoladores durante 25 dias e, durante esse período, amostras de suabe nasal foram coletadas diariamente e sangue coletado semanalmente. No final, os animais foram eutanasiados, necropsiados e fragmentos de órgãos foram coletados para histopatologia, imuno-histoquímica e RT-PCR. No primeiro experimento (BP1), os animais infectados excretaram partículas virais entre os dias 6 e 21 pós-infecção. Quanto ao grupo sentinela, a excreção ocorreu apenas em um animal, no 20ํ dia pós-infecção, e a soroconversão foi observada no 25ํำ dia pós-infecção. Na BP2, os animais infectados I3 e I4 excretaram partículas virais nos dias 4 e 21 pós-infecção, respectivamente. Apenas um animal sentinela (S3) apresentou excreção no dia 13 pós-infecção. Concluiu-se que os suínos podem se infectar com BVDV-1 e excretar partículas virais potencialmente infecciosas, sendo capazes de transmitir o vírus a outros suínos através da lâmina d'água.

TERMOS DE INDEXAÇÃO: Diarreia viral bovina, pestivírus, suínos, RT-PCR, viroses.

\section{INTRODUCTION}

Pestiviruses are of significant importance in swine rearing, as swine can be natural hosts of Classical Swine Fever Virus (CSFV), Bungowannah virus (Kirkland et al. 2007) and of atypical porcine pestivirus (APPV) (Peddireddi et al. 2015) involved in the etiology of congenital tremor in piglets (Arruda et al. 2016). Pigs can also host bovine viral diarrhea virus (BVDV) and border disease virus (BDV).

CSFV strains are the most adapted to pigs and are responsible for great economic losses around the world. However, other pestiviruses such as BVDV can infect pigs resulting in false positives in serological tests to CSFV (Vilcek \& Belàk 1996, Moennig 2000).

Epidemiological studies place cattle as the main host of BVDV, being the most important source of infection for pigs and other wild ruminants (Ridpath 2010). Direct contact with livestock in the same property is considered the primary source of BVDV infections in pigs; transmission may also occur due to the use of raw milk and derivatives from infected cattle in pig feed (Liess \& Moennig 1990).

Great care has been given to infections caused by pestivirus of ruminants in swine, mainly because such infections present some clinical signs similar to classical swine fever (CSF) when swine are infected with CSFV strains of low pathogenicity (Liess \& Moennig 1990).

Water is an important carrier of bacterial and viral pathogens. In commercial finisher pig farms in Brazil is common to find, pens with a water back pond, which is one meter wide with $3-5 \mathrm{~cm}$ of depth that allows the heat exchange of the pigs housed in the barn. It is used to provide conditions for thermal control and welfare; however, it can transmit bacterial and viral agents (Amaral et al. 2003, Flores et al. 2005).

Thus, the present study aimed to induce experimental infection of BVDV-1 in weaned piglets and to assess the shedding and potential transmission of the virus by back pond water.

\section{MATERIALS AND METHODS}

Animals. These experiments were carried out in accordance with the ethical principles adopted by the National Council for the Control of Animal Experimentation (CONCEA) and approved by the Committee on Ethics in the Use of Animals (CEUA) (reference number 07998/14, 08/05/2014).
In this study, 12 weaned piglets of commercial breeds were used, with approximately 21 days old, presenting good body score, weighing five kg in average, from the same litter from a commercial farm with biosecurity standards.

The selection was done after blood collection from the piglets and the sow to confirm the absence of antibodies against BVDV by Virus neutralization (VN), as recommended by the "Manual of Diagnostic Tests and Vaccines of Terrestrial Animals" (OIE 2009).

The piglets were identified with earrings, fed with autoclaved feed and water. The room temperature at which the piglets were housed remained constant at $25^{\circ} \mathrm{C}$.

Isolators. For the assessment of the transmission route, stainless steel isolation cabinets $(0.80 \mathrm{~m} \times 0.80 \mathrm{~m} \times 1.30 \mathrm{~m})$ were used, completely closed and specifically designed for epidemiological studies, according to the design developed from a prototype recommended by some authors (Torremorell et al. 1997, Oliveira et al. 2006, 2007, 2010), belonging to Swine Research Laboratory of the Faculty of Agricultural and Veterinary Science, Unesp, Jaboticabal, Brazil. (Fig.1)

The isolation cabinets allow feed and water input without opening the system, as well as the material for blood and swab collection which are passed through a transition chamber.

Inside each cabinet, there was a back pond which piglets used to refresh themselves. This structure occasionally received feces and urine, as well as oral fluids of the experimented piglets. Cabinets of infected and sentinel piglets were interconnected by a system of hoses to transfer water from one back pond to another, being the only form of contact among the groups. The back pond was renewed and transferred daily, thus ensuring that the sentinel group remained in contact with the back pond of the infected group. Therefore, the back pond water became an important source of pathogens transmission.

The water $\mathrm{pH}$ of each cabinet was analyzed every day in the morning by a bench $\mathrm{pH}$ meter, and the collection was done in a $50 \mathrm{ml}$ graduated tube with a sterile cap.

Ventilation of the system was performed by continuous, non-returning air flow through sterile ducts connecting the cabinets to the ventilating unit and the exhaust fan. Both units, the exhauster (Exhaust flow 500, Filtracom Ltda, Campinas, SP) and the fan (Steril flow 500, Filtracom Ltda) are equipped with HEPA pre-filters and absolute filters, with $99.97 \%$ efficiency for particles bigger than $0.3 \mu \mathrm{m}$.

Experimental design. These experiments were carried out following the ethical principles adopted by the National Council for the Control of Animal Experimentation (CONCEA) and approved by the Committee on Ethics in the Use of Animals (CEUA) (reference number 07998/14, May 8, 2014).

For the experimental inoculation with BVDV-1, the piglets remained in observation for seven days in isolated pen suitable for the breeding phase. During this period, samples of blood and nasal swab were collected, and analyzed using virus neutralization (VN) and RT-PCR respectively (Weinstock et al. 2001), proving that the piglets were seronegative and free of viremia.

Due to the limited capacity of each cabinet, six piglets were used per experiment, randomly assigned into three equal groups $(n=2)$ : control, sentinel and infected, to evaluate the excretion and possible transmission of BVDV-1, as shown in Table 1.

The infected group was inoculated with BVDV-1, Singer strain. Viral inoculum was produced through viral replication in Madine Darby Bovine Kidney (MDBK) cells and later stored in Eagle-Minimal Essential Medium (E-MEM) medium.

Two inoculums were prepared for this study, one for the first and other for the second repetition. The average titer of the inoculum 
was $10^{5,78}$. Determination of titer was performed according to the method proposed previously (Reed \& Muench 1938).

The BVDV inoculation in the infected group followed the method recommended by Cabezón et al. (2010). Scarification on the snout of the piglets was performed to enable the inoculum to be contacted with the bloodstream, and the inoculation in the infected group was done intranasally, by instillation of $2.5 \mathrm{~mL}$ of viral suspension in each nostril, and by oral route with a syringe, being administered the volume of $5.0 \mathrm{~mL}$. Control and sentinel piglets received $10 \mathrm{~mL}$ of placebo containing E-MEM medium, which was given by the same routes.

According to previous studies, seroconversion in pigs occurs generally $21 \mathrm{dpi}$. In this study, each experiment was conducted for 25 days, during which samples of nasal swabs were collected daily and blood collected every 7 days by jugular venipuncture.

At the time of each collection, general clinical evaluation of the piglets was carried out, with rectal temperature measurement and assessment of clinical signs. On the 25th day of the experiment, the piglets were euthanized and necropsied.

Virus neutralization test (VN). Serum samples were submitted to Virus neutralization test. The sera to be tested were collected in duplicates and subjected to successive dilutions starting at $1: 10$ up to $1: 5120$, considering positives the samples that showed total neutralization of the $100 \mathrm{TCID}_{50}$ at a dilution above $1: 10$, as recommended by the "Manual of Diagnostic Tests and Vaccines of Terrestrial Animals" (OIE 2009). For the test were used bovine kidney epithelial cell lineage "Madine-Darby Bovine Kidney" (MDBK) and as standard virus the BVDV-1 (Singer strain) cytopathic (CP). The antibody titer considered for positive samples was equivalent to the reciprocal of the highest dilution in which total neutralization of the $100 \mathrm{TCID}_{50}$ occurred, evidenced by the absence of cytopathic effect in the cell culture.

Histopathology and immunohistochemistry (IHC). Samples of spleen, ileum, lung, kidney, liver, tonsils, and mesenteric, mediastinal, and inguinal lymph nodes were fixed in $10 \%$ buffered formalin and routinely processed for paraffin inclusion and hematoxylin-eosin staining (HE).

The IHC technique was performed in all histological sections, using the technique as described by Haines et al. (1992). Slides were silanized and subjected to antigen retrieval with protease XIV for 15 minutes. Subsequently, endogenous peroxidase blockade was performed with $4 \% \mathrm{H}_{2} \mathrm{O}_{2}$ solution, non-specific binding block

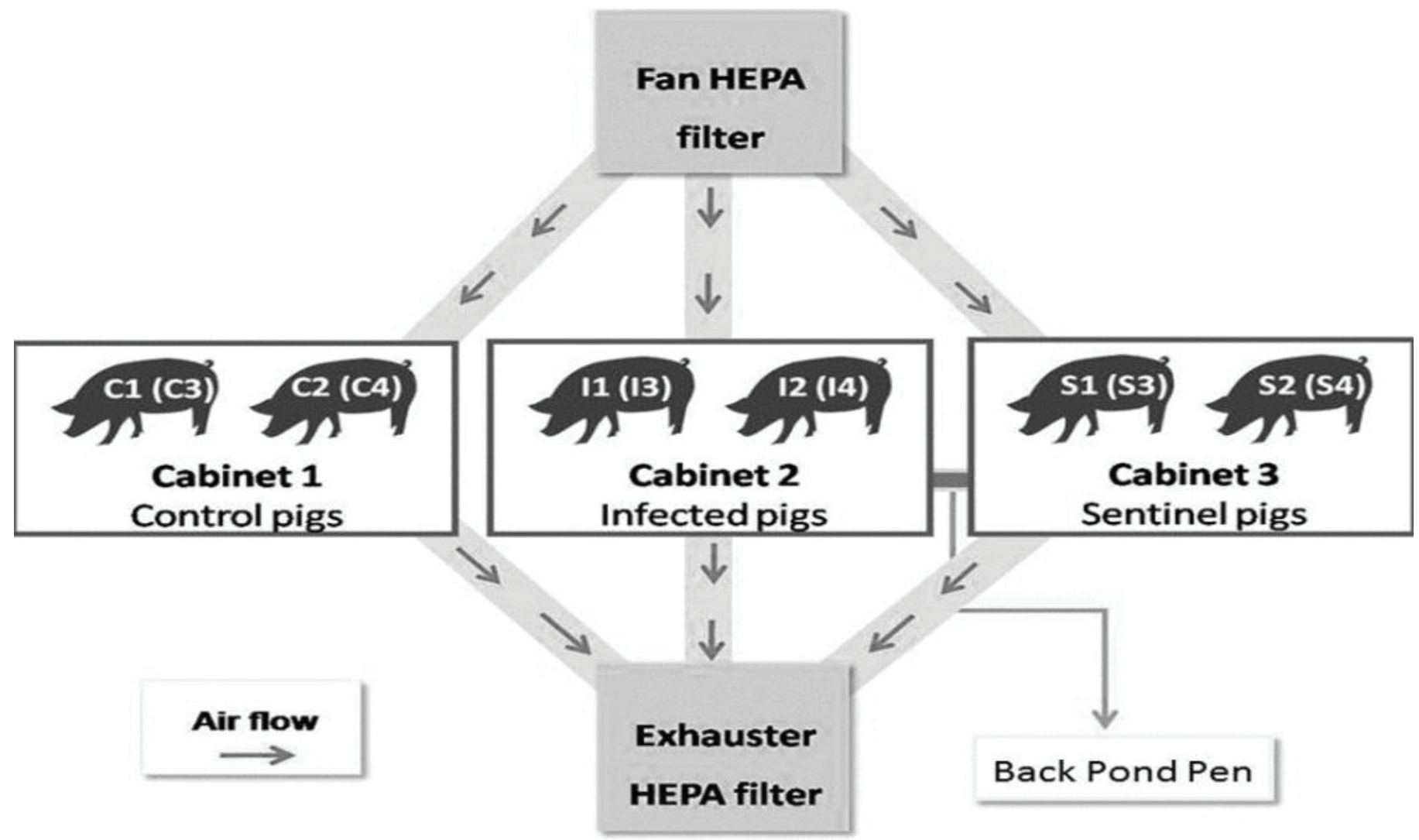

Fig.1. Insulator assembling scheme for the study of transmission route through the back pond. Jaboticabal/SP, Brazil, 2016.

Table 1. Distribution of animals per group in the experiments to assess BVDV transmission via the back pond water, in experimentally infected piglets. Jaboticabal, SP, 2015-2016

\begin{tabular}{cccccc}
\hline Transmission route & ID & No. of infected piglets & No. of sentinel & No. of control & Total per repetition \\
\hline Back pond I & BP I & 2 & 2 & 2 & 6 \\
Back pond II & BP II & 2 & 2 & 2 & 6 \\
\hline
\end{tabular}

ID = Identification of experiments. 
with commercial Kit (DAKO LSAB + System - HRP Biotinylated Link Universal Streptavidin - HRP) and incubation with monoclonal antibody D89 (VMRD, Inc., Pullman, USA) diluted in bovine serum albumin (BSA) at a concentration of 1:150 applied for 14 to 16 hours (overnight) at $4^{\circ} \mathrm{C}$, in a humidified chamber.

The following day, incubation was carried out with the secondary antibody, diaminobenzidine revelation (DAKO- Liquid DAB + Substrate, Chromogen System DAB + Chromogen DAB + Substrate Buffer) and counter-staining with HE. As a positive control of BVDV, a positive fragment of bovine ear epithelium was used in all the tests performed. A section of the analyzed tissue incubated with the antibody diluent (BSA) was used as negative control, thus allowing the evaluation of possible nonspecific reactions.

RT-PCR. Additional samples of nasal swab and samples of spleen, ileum, lung, kidney, liver, tonsils, and mesenteric, mediastinal, and inguinal lymph nodes, lung, kidney, liver and tonsil were evaluated for the presence of BVDV genetic material by RT-PCR. Collected swabs were stored in sterile, RNA-free microtubes containing $0.3 \mathrm{~mL}$ of E-MEM (Eagle's Minimal Essential Medium) supplemented with antibiotics (streptomycin 1\%). As negative control, a sample containing only PCR reagents was used.

RNA from the samples was extracted using Trizol (Sigma) and converted into cDNA by using the kit High-Capacity cDNA Reverse Transcription (Applied Biosystems), According to the manufacturer's instructions. A conventional PCR for virus identification was performed using sense primers 103 (5'-TAG CCA TGC CCT TAG TAG GAC-3') and 392 antisense (5'-ACT CCA TGT GCC ATG TAC AGC-3') which amplifies a product of $290 \mathrm{bp}$ (Weinstock et al. 2001).

The PCR product obtained for the genes identification was used for the reamplification reaction using the same set of primers, aiming at increasing the amount of amplified product. It was conducted employing primers that bind to the highly conserved region of the BVDV genome located in 5' end of the NADL strain, which shares maximum homology with the BVDV genotypes type 1 and 2 .

For the first PCR reaction, buffer $1 \mathrm{X}$ was used $(20 \mathrm{mM}$ Tris- $\mathrm{HCl}$ pH 8.4; $50 \mathrm{mM} \mathrm{KCl}$ ), $2 \mathrm{mM} \mathrm{MgCl}_{2}, 0.2 \mathrm{mM}$ dNTPs, $1.0 \mathrm{U}$ Taq DNA polimerase, 5 pmol of each primer, $5 \mu \mathrm{L}$ of cDNA and water for $20 \mu \mathrm{L}$. Amplification of the fragments occurred in a Nexus thermocycler (Eppendorf) programmed to cycle at $95^{\circ} \mathrm{C}$ for 4 minutes, 35 cycles at $94^{\circ} \mathrm{C}$ for 40 seconds, $60^{\circ} \mathrm{C}$ for 40 seconds, and $72^{\circ} \mathrm{C}$ for 40 seconds, followed by a final cycle of $72^{\circ} \mathrm{C}$ for seven minutes.
The product of the first PCR was used instead of the cDNA to perform the second PCR, which occurred under the same conditions of PCR 1, with the same pair of primers. In all reactions positive controls were used, containing BVDV genetic material and negative controls with the absence of genetic material. The amplification products were submitted to $1 \%(\mathrm{w} / \mathrm{v})$ agarose gel electrophoresis containing ethidium bromide $(0.5 \mathrm{mg} / \mathrm{mL})$, and visualized by Geldoc XR photo documentation equipment (BioRad, USA).

\section{RESULTS}

One infected animal (I1) did not present seroconversion during the sampled period, but viral shedding was detected on days $5,7,8$ and 24 post-infection. In animal I2 seroconversion occurred on the 25th day of the experiment, with antibody titers equal to 20 , and the shedding of the virus was detected in swab samples at 6th, 12th, 15th and 20th dpi. It was also possible to demonstrate the occurrence of transmission because the sentinel animal (S1) seroconverted on 25th dpi, showing antibody titres of 20 and shedding was observed at the 20th dpi. Control piglets (C1 and C2) and sentinel (S2) were negative in all tests performed (Table 2).

In the second repetition of the back pond experiment (BP2), results were similar, showing that infection occurred in the infected group. One infected animal (I4) showed shedding of genetic material on 21st dpi and seroconversion occurred on 25th dpi, with an antibody titre of 20 . The other infected animal (I3) showed excretion in the 4th dpi, but died nine days after infection. Necropsy was conducted followed by organ sample collection. At necropsy, the organs of all piglets did not present lesions, no gross and microscopic lesions were observed. It was also possible to detect virus transmission, since the sentinel animal S3 presented shedding at the $13^{\text {th }} \mathrm{dpi}$, but no seroconversion was detected.

No viral RNA was detected by RT-PCR in the samples of all organ fragments evaluated. Control piglets (C) of both experiments were negative in all tests.

In clinical evaluation, the infected group of both experiments showed clinical signs suggestive of BVDV infection such as diarrhea, shivering, nasal discharge from the 15 th dpi, when compared to control piglets, coinciding with the onset of viral shedding.

Table 2. Results obtained by RT-PCR and Virus neutralization for molecular and serological detection of BVDV and antibodies, detailing the moment of shedding and seroconversion. Jaboticabal, SP, 2015-2016

\begin{tabular}{|c|c|c|c|c|}
\hline \multicolumn{2}{|c|}{ Experiment } & \multirow{2}{*}{$\frac{\text { Viral shedding diagnosed by PCR (dpi) }}{5,7,8,24}$} & \multirow{2}{*}{$\begin{array}{c}\text { Antibodies titres } \\
-\end{array}$} & \multirow{2}{*}{ Moment of antibodies detection (dpi) } \\
\hline BP1 & Infected (I1) & & & \\
\hline & Infected (I2) & $6,12,15,20$ & 20 & $25^{\circ}$ \\
\hline & Sentinel (S1) & 20 & 20 & $25^{\circ}$ \\
\hline & Sentinel (S2) & - & - & - \\
\hline & Control (C1) & - & - & - \\
\hline & Control (C2) & - & - & - \\
\hline \multirow[t]{6}{*}{ BP2 } & Infected (I3) & 4 & - & - \\
\hline & Infected (I4) & 21 & 20 & $25^{0}$ \\
\hline & Sentinel (S3) & 13 & - & - \\
\hline & Sentinel (S4) & - & - & - \\
\hline & Control (C3) & - & - & - \\
\hline & Control (C4) & - & - & - \\
\hline
\end{tabular}

$\overline{\mathrm{dpi}}=$ Days post-infection, $\mathrm{PCR}=$ polymerase chain reaction. 
When measuring the $\mathrm{pH}$ of the back pond water, the results were: control group mean of $6.81 \pm 0.6$, sentinel mean of $6.41 \pm 0.5$; and infected group mean of $6.96 \pm 0.3$.

The results demonstrate that in the experiment BP1 there was successful infection, since there was seroconversion (VN), and viral shedding was detected by RT-PCR in the infected group.

In addition, the tissue evaluation by IHC showed no BVDV positive immunostaining.

\section{DISCUSSION}

The present study was successful in inducing the experimental infection by BVDV in piglets, since there was detection of virus shedding and neutralizing antibody production in the groups of inoculated piglets. Seroconversion of sentinel piglets and detection of viral shedding were also observed, which confirms the transmission through the back pond water. In both groups, inoculated and sentinels, virus shedding was detected before seroconversion.

Virus shedding by infected piglets started between 5 and 10 days post-infection and remained until the end of the 25-day experimental period. In sentinel piglets the shedding was observed only once, and no specific pattern could be determined. The results show an intermittent pattern in the BVDV shedding, suggesting that the BP2 experiment would follow the same intermittent pattern as observed in the BP1 experiment.

Previous studies conducted by Walz et al. (2004), detected antibodies against BVDV in sows five weeks post infection, while Leforban et al. (1992), demonstrated that after inoculation of pigs with a BDV strain, seroconversion occurred within three weeks.

As a consequence of the difficulty of access to BVDV strains isolated from pigs in Brazil, the inoculum for this study was replicated in successive passages in bovine cell line (MDBK), suggesting that the pathogenicity and virulence of the virus used may have been attenuated, which may also lead to a decrease in the amount of virus shed.

BVDV infection is usually asymptomatic, but diarrhea, anemia, rough hair, growth retardation, skin petechiae, chronic gastroenteritis, kidney damage, immunosuppression, and ocular-nasal discharge have been reported in some outbreaks of BVDV in pigs congenitally infected. (Potgieter 2004, Chase 2013, Tao et al. 2013). In the experimentally infected piglets, diarrhea, weight loss, and oculonasal discharge were observed in the piglets of both experiments, and these signs appeared right after the onset of viral shedding.

Regarding the microscopic evaluation, the tissues of the piglets from both experiments did not present lesions when compared to the control animals, thus demonstrating that BVDV was not able to determine lesions in the evaluated organs. In addition, in IHQ there was no BVDV positive immunostaining in the evaluated tissues.

The present study showed that piglets experimentally infected by BVDV-1 shed the agent in different dpi, stating that pigs can actually amplify and propagate BVDV to the environment. This situation can be important for the epidemiology of the disease in the field.

The use of the back pond in finisher sector contributes to the liquefaction of the waste, which could alter the water $\mathrm{pH}$ by the amount of excreta, hindering the virus survival.
By measuring the $\mathrm{pH}$ of the water table, the means found by group were: control 6.81 \pm 0.6 ; Sentinel 6.41 \pm 0.5 ; and infected 6.96 \pm 0.3 .

BVDV is stable in the range of $\mathrm{pH} 5.7$ to 9.3 with maximum stability at pH 7.4 (Hirsh \& Zee 2003). The values obtained with the daily $\mathrm{pH}$ measurement of the back ponds were close to the maximum stability, allowing the viability of this virus in the water and serving as a carrier of pathogens as BVDV, as proven in this study.

The present study showed that BVDV can infect healthy pigs through water, being able to replicate and be shed through the nasal route, making these animals a source of infection for other pigs. It was possible to observe that pigs shed the virus intermittently, and it is not possible to determine a pattern of excretion and seroconversion during the experimental period.

Likewise, the back pond, commonly found in pig farms, can be an important tool in the transmission of BVDV.

Aknowledgements.- This study was supported by São Paulo Research Foundation (FAPESP grant numbers 2014/13590-3). Scholarship Grant (process number 2015/07098-1).

\section{REFERENCES}

Amaral L.A., Nader Filho A., Rossi Junior O.D., Ferreira F.L.A. \& Barros L.S.S. 2003. Água de consumo humano como fator de risco à saúde em propriedades rurais. Revta Saúde Pública 37(4):510-514. <http://dx.doi. org/10.1590/S0034-89102003000400017>

Arruda B.L., Arruda P.H., Magstadt D.R., Schwartz K.J., Dohlman T., Schleining J.A., Patterson A.R., Visek C.A. \& Victoria J.G. 2016. Identification of a divergent lineage porcine pestivirus in nursing piglets with congenital tremors and reproduction of disease following experimental inoculation. PloS One 11(2):e0150104. <http://dx.doi.org/10.1371/journal.pone.0150104> <PMid:26909691>

Cabezón O., Rosell R., Sibila M., Lavín S., Marco I. \& Segalés J. 2010. Experimental infection of pigs with border disease virus isolated from Pyrenean chamois (Rupicapra pyrenaica). J. Vet. Diagn. Invest. 22(3):360-365. <http://dx.doi. org/10.1177/104063871002200303><PMid:20453208>

Chase C.C.C.L. 2013. The impact of BVDV infection on adaptive immunity. Biologicals 41(1):52-60. <http://dx.doi.org/10.1016/j.biologicals.2012.09.009> <PMid:23137817>

Flores E.F., Weiblen R., Vogel F.S.F., Roehe P.M., Alfieri A.A. \& Pituco E.M. 2005. A infecção pelo vírus da diarreia viral bovina (BVDV) no Brasil: histórico, situação atual e perspectivas. Pesq. Vet. Bras. 25(3):125-134. <http:// dx.doi.org/10.1590/S0100-736X2005000300002>

Haines D.M., Clark E.G. \& Dubovi E.J. 1992. Monoclonal antibody-based immunohistochemical detection of bovine viral diarrhea virus in formalinfixed, parafin-embedded tissues. Vet. Pathol. 29(1):27-32. <http://dx.doi. org/10.1177/030098589202900104> <PMid:1313612>

Hirsh D.C. \& Zee Y.C. 2003. Microbiologia Veterinária. Guanabara Koogan, Rio de Janeiro, p.362-365.

Kirkland P.D., Frost M.J., Finlaison D.S., King K.R., Ridpath J.F. \& Gu X. 2007. Identification of a novel virus in pigs-Bungowannah virus: a possible new species of pestivirus. Virus Res. 129(1):26-34.<http://dx.doi.org/10.1016/j. virusres.2007.05.002><PMid:17561301>

Leforban Y., Vannier P. \& Cariolet R. 1992. Protection of piglets born from ruminant pestivirus experimentally infected sows and their contact, to the challenge with hog cholera virus. Annales de Recherches Vétérinaires 23(1):73-82. <PMid:1324630>

Liess B. \& Moennig V. 1990. Ruminant pestivirus infection in pig. Rev. Sci. Tech. OIE 9(1):151-161. <http://dx.doi.org/10.20506/rst.9.1.484> 
Moennig V. 2000. Introduction to classical swine fever: virus, disease and control policy. Vet. Microbiol. 73(2/3):93-102.<http://dx.doi.org/10.1016/ S0378-1135(00)00137-1><PMid:10785320>

OIE 2009. Manual of Diagnostic Tests and Vaccines for Terrestrial Animals. Organização Mundial de Saúde Animal, Paris. Disponível em <http://www. oie.int/fileadmin/Home/eng/Health_standards/tahm/2.08.03_CSF.pdf> Acesso em 10 mar. 2015.

Oliveira C.J., Garcia T.B., Carvalho L.F.O. \& Givisiez P.E. 2007. Nose-to-nose transmission of Salmonella typhimurium between weaned pigs. Vet. Microbiol. 125(3/4):355-361. <http://dx.doi.org/10.1016/j.vetmic.2007.05.032> $<$ PMid:17643873>

Oliveira C.J.B., Carvalho L.F.O.S. \& Garcia T.B. 2006. Experimental airborne transmission of Salmonella Agona and Salmonella Typhimurium in weaned pigs. Epidemiol. Infect. 134(1):199-209. <http://dx.doi.org/10.1017/ S0950268805004668><PMid:16409668>

Oliveira L.G., Carvalho L.F.O.S., Masson G.C.I.H. \& Feliciano M.A.R. 2010. Infecção experimental por Salmonella entérica subespécie enterica sorotipo Panama e tentativa de transmissão naso nasal em leitões desmamados. Arq. Bras. Med. Vet. Zootec. 62(6):1340-1347.<http://dx.doi.org/10.1590/ S0102-09352010000600007>

Peddireddi L., Gauger P.C., Collin E.A., Anderson G., Yuan F., Hause B.M., Fang Y., Hesse R.A., Chen Z. \& Clement T. 2015. Discovery of a novel putative atypical porcine pestivirus in pigs in the USA. J. Gen. Virol. 96(10):29942998. <http://dx.doi.org/10.1099/jgv.0.000251><PMid:26219947>
Potgieter L.N.D. 2004. Bovine viral diarrhoea and mucosal disease, p.946-969. In: Coetzer J.A.W., Thomson G.R. \& Tustin R.C. (Eds), Infectious Diseases of Livestock. Oxford University Press, Cape Town.

Reed L.J. \& Muench H. 1938. A simple method of estimating 50 per cent end point. Am. J. Hyg. 27:493-497.

Ridpath J.F. 2010. Bovine viral diarrhea virus: global status. Vet. Clin. N. Am., Food Anim. Pract. 26(1):105-121. <http://dx.doi.org/10.1016/j. cvfa.2009.10.007><PMid:20117546>

Tao J., Liao J., Wang Y., Zhang X., Wang J. \& Zhu G. 2013. Bovine viral diarrhea virus (BVDV) infections in pigs. Vet. Microbiol. 165(3/4):185-189. <http:// dx.doi.org/10.1016/j.vetmic.2013.03.010> <PMid:23587625>

Torremorell M., Pijoan C., Janni K., Walker R. \& Joo H.S. 1997. Airborne transmission of Actinobacillus pleuropneumoniae and porcine reproductive and respiratory syndrome virus in nursery pigs. Am. J. Vet. Res. 58(8):828832. <PMid:9256964>

Vilcek S. \& Belàk S. 1996. Genetic identification of pestivirus strain Frijters as a border disease virus from pigs. J. Virol. Methods 60(1):103-108. <http://dx.doi.org/10.1016/0166-0934(96)02031-9><PMid:8795011>

Walz P.H., Baker J.C., Mullaney T.P. \& Maes R.K. 2004. Experimental inoculation of pregnant swine with type 1 bovine viral diarrhoea virus. J. Vet. Med. 51(4):191-193. <http://dx.doi.org/10.1111/j.1439-0450.2004.00750. $\mathrm{x}><$ PMid:15228555>

Weinstock D., Bhudevi B. \& Castro A.E. 2001. Single-tube single-enzyme reverse transcriptase PCR assay for detection of BVDV in pooled bovine serum. J. Clin. Microbiol. 39(1):43-46. <http://dx.doi.org/10.1128/ JCM.39.1.343-346.2001><PMid:11136745> 